J. Dairy Sci. 95:3489-3500

http://dx.doi.org/10.3168/jds.2011-4814

(C) American Dairy Science Association ${ }^{\circledR}, 2012$.

\title{
Encapsulation of probiotic bacteria in lamb rennet paste: Effects on the quality of Pecorino cheese
}

\author{
A. Santillo, ${ }^{*}$ M. Albenzio, ${ }^{\star 1}$ A. Bevilacqua, $\dagger$ M. R. Corbo, $†$ and A. Sevi ${ }^{\star}$ \\ *Department of Production Sciences, Engineering, and Economics for Agricultural Systems (PrIME) and \\ †Department of Food Science (DISA), University of Foggia, Via Napoli, 25, 71100 Foggia, Italy
}

\begin{abstract}
Lamb rennet pastes containing encapsulated Lactobacillus acidophilus and a mix of Bifidobacterium longum and Bifidobacterium lactis were produced for Pecorino cheese manufacture from Gentile di Puglia ewe milk. Cheeses were denoted as RP cheese when made with traditional rennet paste, RP-L cheese when made with rennet paste containing L. acidophilus culture, and $\mathrm{RP}-\mathrm{B}$ cheese when made with rennet paste containing a mix of B. lactis and B. longum. Biochemical features of Pecorino cheese were studied at $1,15,30,60$, and $120 \mathrm{~d}$ of cheese ripening. The effect of encapsulation and bead addition to rennet acted on a different way on the viability of probiotic. Lactobacillus acidophilus retained its viability for 4 to $5 \mathrm{~d}$ and then showed a fast reduction; on the other hand, $B$. longum and $B$. lactis experienced kinetics characterized by an initial death slope, followed by a tail effect due to acquired resistance. At $1 \mathrm{~d}$ of ripening, the levels of L. acidophilus and bifidobacteria in cheese were the lowest, and then increased, reaching the highest levels after $30 \mathrm{~d}$; such cell loads were maintained throughout the ripening for L. acidophilus, whereas bifidobacteria experienced a decrease of about $1 \log \mathrm{cfu} / \mathrm{g}$ at the end of ripening. Enzymatic activities and biochemical features of cheeses were influenced by the type of rennet used for cheesemaking. Greater enzymatic activity was recorded in RP-L and RP-B cheese due to the presence of probiotic bacteria released from alginate beads. A positive correlation was found between enzymatic activities and water-soluble nitrogen and proteose-peptone in RP-B and RP-L cheeses; water-soluble nitrogen and proteose-peptone were the highest in RP-B. Principal component analysis distinguished RP-L from the other cheeses on the basis of the conjugated linoleic acid content, which was higher in the RP-L due to the ability of $L$. acidophilus to produce conjugated linoleic acid in the cheese matrix.
\end{abstract}

Received August 9, 2011.

Accepted January 16, 2012.

${ }^{1}$ Corresponding author: m.albenzio@unifg.it
Key words: lamb rennet paste, probiotic, alginate bead, cheese quality

\section{INTRODUCTION}

Pecorino cheese is a typical dairy product associated with sheep husbandry widespread in the Mediterranean area. Pecorino manufacture is still performed using traditional protocols and artisanal procedures, such as the use of rennet paste obtained from the abomasa of suckling lambs or kids. Rennet paste contains a wide spectrum of enzymes that play a role not only in the coagulating phase but also on the lipolytic and proteolytic processes occurring during cheese ripening. The incorporation of probiotic bacteria in rennet paste represents a strategy to obtain typical cheeses with functional characteristics without any modification in Pecorino cheese production protocol (Santillo and Albenzio, 2008; Santillo et al., 2009; Albenzio et al., 2010). Moreover, the same authors verified that the use of probiotic rennet did not affect adversely the composition, texture, and sensory features of the cheese. These results could encourage producers to offer typical products while also adapting to new market requests for healthy dairy products. Indeed, the current consumer market of dairy products requires a continuous effort in terms of quality and innovation.

It is reported that probiotic bacteria may not survive in high numbers when incorporated into dairy products; thus, encapsulation methods have been applied to increase the survival and delivery of bacterial cultures at controlled rates (Sultana et al., 2000; Anal et al., 2006). The interest in this approach has increased because of its promising applications, as entrapped bacteria show improved heat tolerance, prolonged viability, and enhanced survival in simulated gastrointestinal conditions (Kailasapathy, 2002). One of the most promising polymers for cell entrapment is alginate, a polysaccharide belonging to the family of linear and non-repeating polymers; it contains variable amounts of $\beta$-D-mannuronic acid and its C5-epimer $\alpha$-L-guluronic acid, linked through a $\beta$-1,4-glycosidic bond (Remminghorst and Rehm, 2006). Many microorganisms have 
been entrapped successfully in alginate microspheres, like lactobacilli, bifidobacteria, lactococci, and yeasts (Corbo et al., 2011).

At the industrial level Champagne et al. (2000) proposed a continuous method to produce up to $50 \mathrm{~kg} / \mathrm{h}$ of wet alginate beads; furthermore, Corbo et al. (2011) optimized a friendly protocol, based on a syringe extrusion of alginate, followed by a dipping of beads in a solution of $\mathrm{CaCl}_{2}$.

The present study involved the Gentile di Puglia sheep breed, an autochthonous genotype reared in Southern Italy; its milk is destined for lamb feeding and to Pecorino cheese production. In numerous dairy farms, Gentile di Puglia lambs are reared with their dams and abomasa are used to produce rennet paste for typical cheese production. The aim of the work was to study the effect of lamb rennet paste containing encapsulated cells of Lactobacillus acidophilus, and a mix of Bifidobacterium longum and Bifidobacterium lactis on the biochemical features of Pecorino cheese.

\section{MATERIALS AND METHODS}

\section{Analyses of Ewe Milk}

A total of 6 samples of Gentile di Puglia ewe bulk milk used for cheesemaking were analyzed for fat, protein, and lactose content (MilkoScan FT 120; Foss Electric A/S, Hillerød, Denmark), and SCC (Fossomatic Minor, DK-3400; Foss-Electric A/S). Milk renneting characteristics (clotting time, rate of clot formation, and clot firmness after $30 \mathrm{~min}$ ) were measured using a Formagraph (Foss Electric A/S).

\section{Production of Alginate Beads}

Lyophilized cultures of L. acidophilus, B. longum, and $B$. lactis were supplied from Mediterranea Biotecnologie S.r.l. (Termoli, Italy) and grown for $48 \mathrm{~h}$ at $37^{\circ} \mathrm{C}$ in de Man, Rogosa, and Sharpe (MRS) broth (for $L$. acidophilus; Oxoid S.p.A., Milan, Italy) or in MRS + cysteine (cMRS; $0.05 \%$; cysteine was purchased from Sigma-Aldrich S.r.l., Milan, Italy; for bifidobacteria). Cell cultures $(30 \mathrm{~mL})$ were centrifuged at $1,200 \times g$ for $10 \mathrm{~min}$; then, the supernatant was discarded and $30 \mathrm{~mL}$ of sterile distilled water added to the pellet. The beads were prepared as follows: $18 \mathrm{~mL}$ of cell suspension was added to $2 \mathrm{~g}$ of Na-alginate (Fluka, Milan, Italy) and mixed gently for 1 to $2 \mathrm{~min}$. Then, the gel was manually extruded through a sterile $50-\mathrm{mL}$ syringe and the capsules (ca. $2 \times 3 \mathrm{~mm}$ ) were dipped in a $\mathrm{CaCl}_{2}$ solution (0.5\%; J. T. Baker, Milan, Italy) for ca. $5 \mathrm{~min}$ and then air dried for $30 \mathrm{~min}$ on blotting paper. Probiotic strains used in this study were previously tested for their tolerance in a simulated human gastrointestinal system (Bove et al., 2010). The initial cell counts of $L$. acidophilus and bifidobacteria were ca. 8.5 to $9.0 \mathrm{log}$ $\mathrm{cfu} / \mathrm{mL}$.

\section{Rennet Paste}

The abomasa for rennet paste production were extracted from suckling lambs (42 d of age): perivisceral fat was removed and the abomasa were stored in salt at $6^{\circ} \mathrm{C}$ and $70 \%$ relative humidity. After $3 \mathrm{mo}$, the ripened abomasa were ground to obtain a paste, which was kept in a dark glass jar at $4^{\circ} \mathrm{C}$. Lamb rennet paste was characterized by a clotting activity of 110 international milk clotting U/g, chymosin-to-pepsin ratio of 70:30, and a lipolytic activity of 11.33 international lipolytic U/g determined according to Santillo et al. (2007, 2009).

The paste was divided into 3 parts: plain rennet paste $(\mathbf{R P})$; alginate beads (1 $\mathrm{g}$ of spheres for $10 \mathrm{~g}$ of rennet) containing L. acidophilus were added to rennet paste (RP-L); alginate beads (1:10), containing a mix (1:1) of B. longum and B. lactis, were added to rennet paste (RP-B).

\section{Definition of the Shelf Life of Rennet}

Rennet samples, prepared as described above, were stored at $4{ }^{\circ} \mathrm{C}$ and analyzed to assess the viable count of probiotic and naturally occurring microflora. Total viable count $\left(30^{\circ} \mathrm{C}\right.$ for $24-48 \mathrm{~h}$; plate count agar), lactic acid bacteria (LAB; $30^{\circ} \mathrm{C}$ for $48-72 \mathrm{~h}$ under anaerobic conditions on MRS agar), L. acidophilus on acidified MRS, bifidobacteria on cMRS, and Enterobacteriaceae $\left(37^{\circ} \mathrm{C}\right.$ for $18-24 \mathrm{~h}$ on violet red bile agar) were enumerated daily for $30 \mathrm{~d}$. Alginate beads stored at $4^{\circ} \mathrm{C}$ were used as controls.

\section{Pecorino Cheese Production}

Gentile di Puglia ewe's milk was used for Pecorino cheese production. Three Pecorino cheesemaking trials were performed in duplicate at industrial plant scale according to the protocol reported by Santillo and Albenzio (2008) using the 3 different experimental rennet pastes.

Cheeses were denoted RP cheese when made with rennet paste, RP-L cheese when made with rennet paste containing L. acidophilus culture (LA-5), and RP-B cheese when made with rennet paste containing a mix of B. lactis (BB-12) and B. longum (BB-46). Cheeses were sampled and analyzed in duplicate at 1 , $15,30,60$, and $120 \mathrm{~d}$ of ripening. 


\section{Analyses of Cheese}

Chemical Composition and Microbiology of Cheese. The dry matter content, $\mathrm{NaCl}$, and $\mathrm{pH}$ of cheeses were determined according to the International Dairy Federation (IDF, 1986, 1988, 1989, respectively). Total nitrogen, NPN, non-casein nitrogen, and phosphotungstic acid-soluble nitrogen were determined as described by Gripon et al. (1975) and water-soluble nitrogen (WSN) was measured as described by Stadhouders (1960). The total nitrogen minus WSN gave the casein nitrogen; WSN minus NPN gave the proteose-peptone (PP) fraction (Prieto, et al., 2002).

Samples of $20 \mathrm{~g}$ of cheese recovered both from the outer and inner part of cheese were diluted with 180 $\mathrm{mL}$ of saline solution $(0.9 \% \mathrm{NaCl})$ in a stomacher bag and blended for 1 min with a Stomacher Lab Blender 400 (International PBI S.p.A., Milan, Italy). Decimal dilutions of cheese homogenates were performed and microbiological counts were carried out.

The media and the conditions used for the enumerations were as follows: plate count agar, incubated at $7^{\circ} \mathrm{C}$ for 7 to $10 \mathrm{~d}$ or at $30^{\circ} \mathrm{C}$ for $48 \mathrm{~h}$ for psychrotrophic and mesophilic bacteria, respectively; MRS agar, modified by adding $0.17 \mathrm{~g} / \mathrm{L}$ of cycloheximide (Sigma-Aldrich S.r.l.), incubated at $30^{\circ} \mathrm{C}$ and $44^{\circ} \mathrm{C}$ for $4 \mathrm{~d}$ under anaerobic conditions for the evaluation of mesophilic and thermophilic lactobacilli; M17 agar, added to $0.17 \mathrm{~g} / \mathrm{L}$ of cycloheximide, incubated at 30 and $44^{\circ} \mathrm{C}$ for $4 \mathrm{~d}$ under anaerobic conditions for the evaluation of mesophilic and thermophilic lactococci; acidified MRS agar, adjusted to $\mathrm{pH} 5.0$ using $1.0 \mathrm{~N} \mathrm{HCl}$ and incubated at $37^{\circ} \mathrm{C}$ for 48 to $72 \mathrm{~h}$ for the evaluation of L. acidophilus (counts were confirmed by microscopic examination); cMRS agar (MRS + cysteine), added to NPLN solution (nalidixic acid, $750 \mathrm{~g} / \mathrm{L}$; paromomycin sulfate, 10 $\mathrm{mg} / \mathrm{L}$; neomycin sulfate, $5 \mathrm{mg} / \mathrm{L}$; lithium chloride, 150 $\mathrm{mg} / \mathrm{L}$; the supplements were from Sigma-Aldrich S.r.l.; Vinderola and Reinheimer, 1999), incubated at $37^{\circ} \mathrm{C}$ for 48 to $72 \mathrm{~h}$ for the evaluation of bifidobacteria; violet red bile glucose agar, incubated at $37^{\circ} \mathrm{C}$ for 18 to $24 \mathrm{~h}$ for Enterobacteriaceae; Pseudomonas agar base, modified by adding Pseudomonas cetrimide, Fucidin, and cephalotin (CFC)-selective supplement after autoclaving at $121^{\circ} \mathrm{C}$ for $15 \mathrm{~min}$, incubated at $30^{\circ} \mathrm{C}$ for $48 \mathrm{~h}$, for Pseudomonas spp.; and Baird-Parker medium, added to egg yolk tellurite emulsion, incubated at $37^{\circ} \mathrm{C}$ for 48 $\mathrm{h}$ for staphylococci. All of the media and the supplements used were from Oxoid S.p.A. The analyses were performed in duplicate and cell counts were confirmed by microscopic examination. Starting from $60 \mathrm{~d}$ of ripening, the beads were no longer visually detectable in cheese.
Determination of Plasmin Content in Cheese. Plasmin (PL) activity was determined in cheese throughout ripening according to Santillo and Albenzio (2008). A standard curve was prepared to convert PL (Sigma Chemical Co., St. Louis, MO) activity to PL concentration by plotting changes in absorbance against concentrations of PL over a range from 0 to16 $\mu \mathrm{g} / \mathrm{mL}$. The PL concentration was reported as $\mu \mathrm{g} / \mathrm{mg}$ of cheese.

Enzymatic Activities in Water-Soluble Cheese Extract. Sterile, dialyzed, water-soluble extracts of the cheeses were prepared according to the method of Kuchroo and Fox (1982). The extracts were dialyzed for $24 \mathrm{~h}$ at $4^{\circ} \mathrm{C}$ against $0.05 \mathrm{M}$ phosphate buffer ( $\mathrm{pH}$ 7.0) using dialysis tubing (cut-off $12 \mathrm{kDa}$; Sigma Chemical Co.) and then subjected to sterile filtration $(0.22-\mu \mathrm{m}$ pore size, Syrfil filter, Nucleopore; Costar Co., Cambridge, UK) to avoid interference from salts and peptides, and cellular activity. Peptidase activities were determined as described by Gobbetti et al. (1997) using Ala- $p \mathrm{NA}$, Leu- $p \mathrm{NA}$, Lys- $p \mathrm{NA}$, Pro- $p \mathrm{NA}$ (where $p \mathrm{NA}=$ $p$-nitroanilide; Sigma Chemical Co.) as substrates. A unit of enzymatic activity was defined as the amount of enzyme that produced $1 \mu \mathrm{mol}$ of para-nitroanilide per $\min$ at $37^{\circ} \mathrm{C}$ and $\mathrm{pH}$ 7.0.

Electrophoretic Analysis of Cheese. The $\mathrm{pH}$ 4.6-insoluble $\mathrm{N}$ fractions of Pecorino cheese were analyzed by urea-PAGE using a Protean II xi vertical slab gel unit (Bio-Rad Laboratories Ltd., Watford, UK). The stacking and resolving gel system was prepared as described by Andrews (1983). The gels were stained according to the method of Blakesley and Boezi (1977) with Coomassie Brilliant Blue G250. The destained gels were acquired by means of the Gel Doc EQ system (Bio-Rad Laboratories Ltd.) using a white light conversion screen and analyzed with Quantity One software (Bio-Rad Laboratories Ltd.) to determine the signal intensity (optical density) of the defined bands. Bands were identified by comparison with urea-PAGE electrophoretograms obtained under comparable conditions (Trujillo et al., 2000; Bustamante et al., 2003; Santillo et al., 2007). Given $100 \%$ the sum of the intensity of the defined bands in a lane, the relative quantity of each band was determined as the percentage of the signal intensity of the defined bands in a lane.

Determination of Textural Parameters in Cheese. Samples for cheese texture analysis were obtained by cutting a 1-cm-thick slice from the central diameter of the cheese wheel at 15, 30,60, and 120 $\mathrm{d}$ of ripening. Then, 6 rectangular parallelepipeds, 1 $\times 1 \mathrm{~cm}$ thick and $2 \mathrm{~cm}$ long, were obtained from the slide. The cheese samples were left at $20^{\circ} \mathrm{C}$ for $10 \mathrm{~min}$ before testing. Texture profile analysis was evaluated 
with an Instron 4301 tensile tester (Instron Ltd., High Wycombe, UK), using a modified compression device that avoids transversal elongation of the samples. Each sample underwent 2 cycles of $80 \%$ compression; force $x$ time data were used to calculate the following parameters: hardness, cohesiveness, springiness, gumminess, and chewiness.

Determination of FFA and Conjugated Linoleic Acid in Cheese. Total lipids from cheeses were extracted according to de Jong and Badings (1990). Briefly, $1.0 \mathrm{~g}$ of cheese was mixed with $3 \mathrm{~g}$ of anhydrous $\mathrm{Na}_{2} \mathrm{SO}_{4}, 0.3 \mathrm{~mL}$ of $2.5 \mathrm{M} \mathrm{H}_{2} \mathrm{SO}_{4}$, and $0.5 \mathrm{mg}$ of internal standard solution (C13:0). The mixture was extracted 3 times with $3 \mathrm{~mL}$ of ether/hexane (1:1, vol:vol). Each time the solution was heated for $10 \mathrm{~min}$ at $40^{\circ} \mathrm{C}$, centrifuged at $1,258 \times g$ for $5 \mathrm{~min}$, and the supernatant recovered. Free FA were isolated using Bond Elut aminopropyl columns (Sigma Chemical Co.) conditioned with $10 \mathrm{~mL}$ of hexane. The lipid extract was applied to the column and the neutral lipids were eluted with 10 $\mathrm{mL}$ of chloroform/hexane (1:1, vol:vol). The FFA were eluted with $5 \mathrm{~mL}$ of diethyl ether containing $2 \%$ formic acid. Free FA derivatization was performed according to Morrison and Smith (1964). Briefly, the ether extract was dried under a stream of nitrogen, and then 2 $\mathrm{mL}$ of hexane and $2 \mathrm{~mL}$ of boron trifluoride-methanol $\left(\mathrm{BF}_{3}-\mathrm{MeOH} ; 14 \%\right.$, wt/vol $)$ were added. The mixture was heated at $90^{\circ} \mathrm{C}$ for $3 \mathrm{~min}$ and then cooled in ice. The esters were extracted by adding $1 \mathrm{~mL}$ of $\mathrm{H}_{2} \mathrm{O}$ and $2 \mathrm{~mL}$ of hexane; after centrifugation at $500 \times g$ for 10 min, the upper layer was used for gas chromatography. Free conjugated linoleic acid (CLA) and FA were separated on a capillary column (HP88; $100 \mathrm{~m} \times 0.25 \mathrm{~mm}$ i.d., 0.20- $\mu \mathrm{m}$ film thickness; Agilent Technologies Santa Clara, CA). The individual FA peaks were identified by comparison of retention times with those of known mixture of standard FA (Sigma-Aldrich Chemie GmbH, Steinheim, Germany). Pure CLA isomers were purchased as fatty acid methyl esters from Matreya Inc. (Pleasant Gap, PA). The injector and flame ionization detector temperatures were $260^{\circ} \mathrm{C}$. The programmed temperature was $100^{\circ} \mathrm{C}$ for $1 \mathrm{~min}$, increased to $240^{\circ} \mathrm{C}$ at a rate of $3.5^{\circ} \mathrm{C} / \mathrm{min}$, and maintained at $240^{\circ} \mathrm{C}$ for 15 min. The split ratio was 1:50 and helium was the gas carrier with a pressure of $227.52 \mathrm{~Pa}$.

\section{Statistical Analysis}

Data on probiotic cell count in rennet paste were modeled through the Weibull equation, cast in the form of Mafart et al. (2002):

$$
\log N=\log N_{0}-(t / \delta)^{p},
$$

where $\log N$ is the cell count at time $t(\log \mathrm{cfu} / \mathrm{mL})$; $\log N_{0}$ is the initial viable count; $\delta$ is the first reduction time (i.e., the time to attain a $1-\log$ reduction in the population number, $\mathrm{d})$; and $p$ is the shape parameter $(p$ $<1$, downward curve; $p>1$, upward curve).

The shelf life $(s l)$, defined as the time to attain a cell count of $6 \log \mathrm{cfu} / \mathrm{g}$ (Rosburg et al., 2010), was evaluated by means of the parameters of Weibull equation as follows:

$$
s l=\delta \cdot\left[\log \left(\frac{N_{0}}{6.00}\right)\right]^{1 / p} .
$$

Data also were modeled through the Weibull equation, reparameterized by Bevilacqua et al. (2008):

$$
\left(\log _{10} N / \log _{10} N_{0}\right)=1-(t / \text { d.t })^{p} \text {, }
$$

where d.t is the death time (d).

Finally, data fitting was performed through the equation of Geeraerd et al. (2000) for the estimation of the shoulder length (i.e., the time before the beginning of the exponential death phase) and tail effect (residual population). All of the variables were tested for normal distribution using the Shapiro-Wilk test (Shapiro and Wilk, 1965) and transformed in logarithmic form to normalize their frequency distribution, when necessary. Data on cheese composition, enzymatic activities, FFA, and CLA, and on rheological parameters in cheese were processed by ANOVA using the GLM procedure of SAS (SAS Institute, 2011). The tested effects were type of rennet (RP, RP-L, or RP-B), time of ripening (1, 30, 60 , or $120 \mathrm{~d}$ ) and their interactions. When significant effects were found (at $P<0.05$ ), the Tukey test was used as a post hoc test.

Linear simple correlation between casein degradation products, WSN, PP, and enzymatic activities were studied in cheeses. Principal component analysis was performed using the PRINCOMP procedure of SAS to obtain a visual representation of FFA and CLA isomer distribution in cheeses during ripening.

\section{RESULTS AND DISCUSSION}

\section{Microbial Characteristics of Lamb Rennet Paste}

The critical threshold of viable probiotic is $6 \log \mathrm{cfu} / \mathrm{g}$, as this level of population is the minimum required for probiotic action in the small intestine (Rosburg et al., 2010); thus, this level was set as the critical breakpoint for the beads. Weibull parameters of $L$. acidophilus and 
Table 1. Weibull parameters ( \pm SE) of Lactobacillus acidophilus and Bifidobacterium longum and Bifidobacterium lactis in the rennet, after release by beads ${ }^{1}$

\begin{tabular}{lcccccc}
\hline $\begin{array}{l}\text { Rennet } \\
\text { type }^{2}\end{array}$ & $N_{0}$ & $\delta$ & $p$ & $\mathrm{R}^{2}$ & $s l$ & d.t \\
\hline RP-L & $7.35 \pm 0.19^{\mathrm{a}}$ & $4.92 \pm 0.13^{\mathrm{a}}$ & $1.46 \pm 0.05^{\mathrm{a}}$ & 0.966 & 6.05 & $18.20 \pm 0.68^{\mathrm{a}}$ \\
RP-B & $6.92 \pm 0.08^{\mathrm{a}}$ & $1.94 \pm 0.03^{\mathrm{b}}$ & $0.63 \pm 0.02^{\mathrm{b}}$ & 0.970 & 1.70 & $39.44 \pm 0.75^{\mathrm{b}}$ \\
\hline
\end{tabular}

a,b Within each column, data with different letters are significantly different (Student's $t$-test, $P<0.05$ ).

${ }^{1} N_{0}=$ initial cell count $(\log \mathrm{cfu} / \mathrm{g}) ; \delta=$ first reduction time (i.e., the time to attain a 1 -log reduction in the population number, $\mathrm{d}) ; p=$ shape parameter $(p<1$, downward curve; $p>1$, upward curve); sl = shelf life (i.e., time to attain a critical threshold of $6 \log \mathrm{cfu} / \mathrm{g}) ;$ d.t $=$ death time $(\mathrm{d})$.

${ }^{2} \mathrm{RP}-\mathrm{L}=$ rennet paste containing encapsulated Lactobacillus acidophilus; $\mathrm{RP}-\mathrm{B}=$ rennet paste containing encapsulated Bifidobacterium longum and Bifidobacterium lactis.

of $B$. longum and B. lactis released by alginate beads in rennet are reported in Table 1 . The model fit the data satisfactorily, as shown by the regression coefficient. Lactobacillus acidophilus and the combination of B. longum and B. lactis experienced a different death kinetic, as one could infer from the shape parameter: $L$. acidophilus highlighted a downward curve, characterized by an initial phase when cell count did not decrease or did it slowly. On the other hand, B. longum and $B$. lactis stood for an upward kinetic [i.e., a trend characterized by an initial fast decrease of cell count, followed by a tail effect (i.e., a residual level of the target for a prolonged storage time)]. The first reduction time for primary growth/death model indicates the time to attain a reduction of cell count of $1 \log \mathrm{cfu} / \mathrm{g}$ and was higher for L. acidophilus than for the mix of bifidobacteria. Combining the primary fitting parameters and using a critical threshold for cell count of $6 \log \mathrm{cfu} / \mathrm{g}$, shelf life was evaluated, resulting in 6.05 and $1.70 \mathrm{~d}$ for lactobacilli and bifidobacteria, respectively. After the time points evaluated, cells in the beads continued to live and were released in the rennet or in the cheese during cheese making. The use of a reparameterized version of the Weibull equation allowed the evaluation of cell death time, corresponding to 18.20 and $39.44 \mathrm{~d}$ for lactobacilli and bifidobacteria, respectively.

The evaluation of the shape parameter (parameter $p$ of the Weibull equation), as well as the fitting procedure to attain first reduction time, shoulder length, and death time values, highlighted some important details on the different death kinetic experienced by $L$. acidophilus and bifidobacteria. For L. acidophilus, cells experienced a death kinetic characterized by at least 2 phases: a shoulder length and an exponential death phase. The practical implications of this kind of curve were very strong: cell counts of L. acidophilus, released by beads in the rennet retained their viability for 4 to $5 \mathrm{~d}$, without any significant decrease. Thereafter, a fast reduction was observed, thus suggesting that the effect of environment (e.g., rennet) became significant after a prolonged exposure time. On the other hand, the combination of B. longum and B. lactis experienced a kinetic characterized by an initial death slope, then followed by a tail, thus highlighting that, for these microorganisms, the adverse effect influenced the viability of the target microorganisms just after the release from beads. Then, cells probably acquired a kind of resistance, resulting in the tail effect.

\section{Gentile di Puglia Ewe Milk and Cheese Quality}

Gentile di Puglia ewe bulk milk composition, SCC, and coagulation performance is reported in Table 2 . Raw milk had good hygienic quality in terms of SCC, which exhibited values lower than 500,000 cells/mL, in agreement with previous findings of Albenzio et al. (2011). The high content of fat and protein of Gentile di Puglia milk led to good coagulating performance of milk, confirmed by cheese yields, which showed mean values of $20.4 \pm 0.98 \%$ among the experimental cheesemaking trials.

Cell counts of the different microorganisms (both the naturally occurring microflora and that released by beads) just after cheese making and during ripening are reported in Table 3. Cheese microflora is generally composed of genera belonging to the group of LAB, along with some spoiling or hygiene indicator microorganisms

Table 2. Gentile di Puglia ewe bulk milk composition, SCC, and renneting parameters (values expressed as mean $\pm \mathrm{SE}$ )

\begin{tabular}{lc}
\hline Parameter & $\begin{array}{c}\text { Value in } \\
\text { ewe milk }\end{array}$ \\
\hline Fat, \% & $8.41 \pm 0.32$ \\
Protein, \% & $5.95 \pm 0.10$ \\
Lactose, \% & $4.19 \pm 0.10$ \\
Casein, \% & $4.59 \pm 0.10$ \\
SCC, $\log _{10}$ cells $/ \mathrm{mL}$ & $2.76 \pm 0.08$ \\
Clotting time, min & $19.30 \pm 0.49$ \\
Rate of firming, min & $2.15 \pm 0.66$ \\
Curd firmness, mm & $50.24 \pm 3.9$ \\
\hline
\end{tabular}


(Pseudomonas spp., staphylococci, Enterobacteriaceae, and pathogenic bacteria). Cheeses analyzed throughout this research showed Enterobacteriaceae, Pseudomonas spp., and staphylococci at an undetectable level for the entire running time, thus suggesting good quality of the raw materials as well as good processing. Concerning the naturally occurring microflora, LAB represent the main group able to colonize dairy products. Thermophilic LAB strains are generally used as starter cultures in many kind of products; on the other hand, mesophilic lactobacilli and lactococci prevail in natural fermentations (Di Cagno et al., 2010). Due to the fact that cheese making was conducted without whey cultures, the naturally occurring microflora of cheese was mainly composed of mesophilic lactic acid bacteria, ca. $4 \log \mathrm{cfu} / \mathrm{g}$ at the beginning and then increasing significantly throughout storage; this result was also confirmed by total viable count. Thermophilic LAB were at an undetectable level for the entire running time (data not shown).

The levels of L. acidophilus and bifidobacteria, confirmed also by microscopic examination, were at low levels (ca. $2 \log \mathrm{cfu} / \mathrm{g}$ ), then increased significantly within the storage, due to release from beads; after $60 \mathrm{~d}$, cell numbers of L. acidophilus and bifidobacteria were 7.52 and $6.84 \mathrm{log} \mathrm{cfu} / \mathrm{g}$, respectively. Throughout storage, bifidobacteria experienced a decrease, reaching a level of $5.44 \log \mathrm{cfu} / \mathrm{g}$.

\section{Enzymatic Activities and Biochemical Features in Cheese}

Plasmin, aminopeptidase, and proline iminopeptidase activities in cheeses produced using different rennet paste are reported in Table 4. Plasmin originates from milk and is involved in the primary proteolytic process being mainly responsible for $\beta$-CN hydrolysis. Due to its origin, plasmin activity was not different among cheeses but tended to increase at the end of ripening. On the contrary, aminopeptidase and proline iminopeptidase activities detected in water-soluble cheese extract were affected by the type of rennet. An increase in enzymatic activity was observed during ripening, which reached the maximum level at $60 \mathrm{~d}$ for Ala- $p$-NA, Arg- $p$-NA, and Pro- $p$-NA. Overall, greater enzymatic activity was recorded in cheese obtained using rennet paste containing probiotics and the changes over time seem to reflect the liberation of probiotic from alginate beads. The concentration of accessible enzymes liberated after bacterial cell lysis together with variations in specificity,

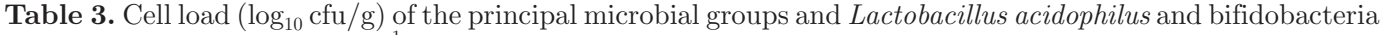
in RP, RP-L, and RP-B cheese ${ }^{1}$

\begin{tabular}{|c|c|c|c|c|}
\hline \multirow[b]{2}{*}{ Item } & \multicolumn{4}{|c|}{ Ripening time, d } \\
\hline & 0 & 30 & 60 & 120 \\
\hline \multicolumn{5}{|c|}{ Mesophilic bacteria } \\
\hline $\mathrm{RP}$ & $5.45^{\mathrm{a}, \mathrm{A}}$ & $6.79^{\mathrm{b}, \mathrm{A}}$ & $7.26^{\mathrm{b}, \mathrm{A}}$ & $7.08^{\mathrm{b}, \mathrm{A}}$ \\
\hline RP-L & $5.34^{\mathrm{a}, \mathrm{A}}$ & $6.86^{\mathrm{b}, \mathrm{A}}$ & $7.48^{\mathrm{c}, \mathrm{A}}$ & $6.72^{\mathrm{b}, \mathrm{AB}}$ \\
\hline RP-B & $5.22^{\mathrm{a}, \mathrm{A}}$ & $6.78^{\mathrm{c}, \mathrm{A}}$ & $7.36^{\mathrm{d}, \mathrm{A}}$ & $6.08^{\mathrm{b}, \mathrm{B}}$ \\
\hline \multicolumn{5}{|c|}{ Mesophilic lactobacilli } \\
\hline $\mathrm{RP}$ & $4.23^{\mathrm{a}, \mathrm{A}}$ & $7.58^{\mathrm{b}, \mathrm{A}}$ & $7.15^{\mathrm{b}, \mathrm{A}}$ & $6.92^{\mathrm{b}, \mathrm{A}}$ \\
\hline RP-L & $4.51^{\mathrm{a}, \mathrm{A}}$ & $7.49^{\mathrm{c}, \mathrm{A}}$ & $7.68^{\mathrm{c}, \mathrm{B}}$ & $7.26^{\mathrm{bc}, \mathrm{A}}$ \\
\hline RP-B & $4.55^{\mathrm{a}, \mathrm{A}}$ & $7.32^{\mathrm{b}, \mathrm{A}}$ & $7.32^{\mathrm{b}, \mathrm{AB}}$ & $6.16^{\mathrm{c}, \mathrm{B}}$ \\
\hline \multicolumn{5}{|c|}{ Mesophilic lactococci } \\
\hline $\mathrm{RP}$ & $4.12^{\mathrm{a}, \mathrm{A}}$ & $6.69^{\mathrm{b}, \mathrm{A}}$ & $7.11^{\mathrm{b}, \mathrm{A}}$ & $7.12^{\mathrm{b}, \mathrm{A}}$ \\
\hline RP-L & $4.33^{\mathrm{a}, \mathrm{A}}$ & $6.39^{\mathrm{bc}, \mathrm{A}}$ & $7.63^{\mathrm{d}, \mathrm{AB}}$ & $6.88^{\mathrm{c}, \mathrm{A}}$ \\
\hline RP-B & $4.44^{\mathrm{a}, \mathrm{A}}$ & $5.36^{\mathrm{b}, \mathrm{B}}$ & $7.24^{\mathrm{c}, \mathrm{A}}$ & $8.30^{\mathrm{d}, \mathrm{B}}$ \\
\hline \multicolumn{5}{|c|}{ L. acidophilus } \\
\hline $\mathrm{RP}$ & $-^{2}$ & - & - & - \\
\hline RP-L & $2.11^{\mathrm{a}}$ & $7.57^{\mathrm{c}}$ & $7.52^{\mathrm{c}}$ & $6.92^{\mathrm{bc}}$ \\
\hline RP-B & - & - & - & - \\
\hline \multicolumn{5}{|c|}{ Bifidobacteria } \\
\hline $\mathrm{RP}$ & - & - & - & - \\
\hline RP-L & - & - & - & - \\
\hline RP-B & $2.45^{\mathrm{a}}$ & $6.89^{c}$ & $6.84^{\mathrm{c}}$ & $5.44^{\mathrm{b}}$ \\
\hline
\end{tabular}

${ }^{\mathrm{a}-\mathrm{d}}$ Means within a row with different superscript lowercase letters differ $(P<0.05)$.

${ }^{\mathrm{A}, \mathrm{B}}$ For each time of analysis and medium, different superscript uppercase letters indicate significant differences $(P<0.05)$ among the samples.

${ }^{1} \mathrm{RP}=$ rennet paste; $\mathrm{RP}-\mathrm{L}=$ rennet paste containing encapsulated $L$. acidophilus; $\mathrm{RP}-\mathrm{B}=$ rennet paste containing encapsulated Bifidobacterium longum and Bifidobacterium lactis.

${ }^{2}$ Below the detection limit (1 log cfu/g). 
stability, and kinetics are the most significant factors that determine the real contribution of adjunct microflora to cheese ripening. Moreover, cell lysis leads to release of intracellular enzymes into the cheese matrix, resulting in end products that are quantitatively and qualitatively different from those produced by intact bacteria (Wallace and Fox, 1997). A great variety of peptidolytic enzymes have been detected in most species of Lactobacillus, including L. acidophilus (Khalid and Marth, 1990). Bifidobacterium spp. are comparable to LAB by the presence of a general aminopeptidase activity encompassing several dipeptidases and possibly iminopeptidase and tripeptidases (Shihata and Shah, 2000). Aminopeptidase and iminopeptidase activities were isolated from a cell-free extract of Bifidobacterium breve, Bifidobacterium infantis, and B. longum (El-Soda et al., 1992). Canestrato Pugliese cheese produced using fresh cells of $B$. longum and B. bifidum displayed higher amino-, imino-, and dipeptidase activities than the control cheese, which was responsible for the highest concentration of the $\mathrm{pH}$ 4.6-soluble $\mathrm{N}$ fraction (Corbo et al., 2001). Aminopeptidases are thought to be of ultimate importance for the development of flavor in fermented milk products because they are capable of releasing single AA residues from oligopeptides formed by extracellular proteinase activity (Shihata and Shah, 2000).

Changes in the principal chemical parameters and ripening indexes of cheese produced using different rennet pastes are reported in Table 5. The activities of ripening enzymes in the curd are very important for cheese ripening; the use of rennet paste rules the coagulation process but chymosin retained in the cheese curds is responsible for the degradation of casein fractions, especially $\alpha-\mathrm{CN}$. At $60 \mathrm{~d}$ of ripening, non-casein nitrogen concentration was comparable with that in the study of Santillo and Albenzio (2008) on Pecorino cheese containing live cells of the same probiotic strains used in the present study. The different method for the adjunct of probiotic adjunct in cheese did not influence the primary proteolysis due to the limited contribution of microorganisms to the initial stages of casein disruption; in fact, this is mainly attributed to rennet enzyme and plasmin activity. Furthermore, Bergamini et al. (2006) added L. acidophilus in cheese using lyophilized cultures or pre-incubated cultures in a substrate com-

Table 4. Plasmin, aminopeptidase, and proline iminopeptidase activities in cheeses produced using different lamb rennet pastes

\begin{tabular}{|c|c|c|c|c|c|c|c|c|}
\hline \multirow[b]{2}{*}{ Parameter $^{1}$} & \multirow[b]{2}{*}{$\begin{array}{c}\text { Ripening } \\
\text { time, d }\end{array}$} & \multicolumn{3}{|c|}{ Lamb rennet paste ${ }^{2}$} & \multirow[b]{2}{*}{ SEM } & \multicolumn{3}{|c|}{ Effect, $P$-value } \\
\hline & & $\mathrm{RP}$ & RP-L & RP-B & & Rennet & Time & $\begin{array}{l}\text { Rennet } \\
\times \text { time }\end{array}$ \\
\hline \multirow{3}{*}{$\mathrm{PL}, \mathrm{U} / \mathrm{g}$} & 30 & 16.8 & 18.2 & 17.01 & & & & \\
\hline & 60 & 13.6 & 16.01 & 14.6 & & & & \\
\hline & 120 & 17.6 & 26.2 & 20.8 & 1.88 & NS & $* * *$ & NS \\
\hline \multirow{2}{*}{ Leu- $p \mathrm{NA}, \mathrm{U} / \mathrm{g}$} & 60 & $1.16^{\mathrm{a}}$ & $2.41^{\mathrm{b}}$ & $4.2^{\mathrm{c}}$ & & & & \\
\hline & 120 & $0.05^{\mathrm{a}}$ & $4.24^{\mathrm{b}}$ & $4.41^{\mathrm{b}}$ & 0.3 & $* * *$ & $* * *$ & $* * *$ \\
\hline \multirow{4}{*}{ Lys- $p \mathrm{NA}, \mathrm{U} / \mathrm{g}$} & 1 & $6.2^{\mathrm{a}}$ & $10.58^{\mathrm{b}}$ & $6.75^{\mathrm{a}}$ & & & & \\
\hline & 30 & $2.37^{\mathrm{a}}$ & $5.33^{\mathrm{b}}$ & $3.46^{\mathrm{a}}$ & & & & \\
\hline & 60 & $2.41^{\mathrm{a}}$ & $5.45^{\mathrm{b}}$ & $4.55^{\mathrm{b}}$ & & & & \\
\hline & 120 & $0.19^{\mathrm{a}}$ & $5.58^{\mathrm{b}}$ & $7.96^{\mathrm{c}}$ & 0.4 & $* * *$ & $* * *$ & $* * *$ \\
\hline Ala- $p \mathrm{NA}, \mathrm{U} / \mathrm{g}$ & 1 & $10.25^{\mathrm{b}}$ & $7.42^{\mathrm{a}}$ & $7.29^{\mathrm{a}}$ & & & & \\
\hline \multirow{2}{*}{$\operatorname{Arg}-p \mathrm{NA}, \mathrm{U} / \mathrm{g}$} & 60 & $4.25^{\mathrm{a}}$ & $7.17^{\mathrm{b}}$ & $16.08^{\mathrm{c}}$ & & & & \\
\hline & 120 & $2.25^{\mathrm{a}}$ & $4.83^{\mathrm{b}}$ & $4.58^{\mathrm{b}}$ & 0.35 & $* * *$ & $* * *$ & $* * *$ \\
\hline \multirow{4}{*}{ Pro- $p$ NA, U/g } & 1 & 3.41 & 4.33 & 4.54 & & & & \\
\hline & 30 & $0.05^{\mathrm{a}}$ & $4.54^{\mathrm{b}}$ & $4.29^{\mathrm{b}}$ & & & & \\
\hline & 60 & $0.05^{\mathrm{a}}$ & $20.91^{\mathrm{b}}$ & $24.12^{\mathrm{c}}$ & & & & \\
\hline & 120 & $0.05^{\mathrm{a}}$ & $4.96^{\mathrm{c}}$ & $2.2^{\mathrm{b}}$ & 0.35 & $* * *$ & $* * *$ & $* * *$ \\
\hline
\end{tabular}

${ }^{\mathrm{a}-\mathrm{c}}$ Means within a row with different superscript letters differ $(P<0.05)$.

${ }^{1} \mathrm{PL}=$ plasmin; $p \mathrm{NA}=p$-nitroanilide.

${ }^{2} \mathrm{RP}=$ rennet paste; RP-L = rennet paste containing encapsulated Lactobacillus acidophilus; RP-B = rennet paste containing encapsulated Bifidobacterium longum and Bifidobacterium lactis.

*** $P<0.001$. 
posed of milk and milk fat; apart from the methodology of culture addition, the tested strain of $L$. acidophilus exhibited an ability to accelerate cheese ripening and to promote flavor enhancement. Nonprotein nitrogen, WSN, and PP displayed a maximum concentration at $60 \mathrm{~d}$ of ripening in RP-L and RP-B cheeses as a consequence of the highest cell count for L . acidophilus and bifidobacteria, respectively. In the subsequent aging, the same fractions underwent a reduction due to further hydrolysis of low-molecular weight peptides and AA. It is worth noting that WSN and PP showed the highest value in RP-B cheese, which is in accordance with the high proteolytic potential of bifidobacteria species. The increase in the phosphotungstic acid-soluble nitrogen fraction in RP-B cheese between 60 and 120 $\mathrm{d}$ of ripening evidenced the ability of bifidobacteria to act over an extended ripening time. Moisture content in cheese underwent a reduction during ripening, which was different among experimental cheeses: RP cheese evidenced a gradual reduction over the 4 mo of ripening, whereas the RP-L and RP-B cheeses experienced a greater reduction after 2 mo. At 120 d of ripening, the lowest moisture content detected in RP-B cheese could be an outcome of the highest WSN and PP; as each peptide bond is cleaved, 2 new ionic groups are generated and each of these will compete for the available water in the system. Thus, the water previously available for solvation of the protein chains will became tied up with the new ionic groups (Lawrence et al., 1987). Mechanical properties of cheese are related to the composition, structure, and strength of the attractions between the structural elements of the cheese (Santillo and Albenzio, 2011). At the end of ripening, cheese hardness was the highest in RP-B cheese $(60.41$ $\pm 1.70,42.60 \pm 1.68$, and $43.18 \pm 1.65 \mathrm{~N}$; mean \pm SEM) according to different levels of proteolysis in

Table 5. Chemical composition and nitrogen fractions in cheeses produced using different lamb rennet pastes

\begin{tabular}{|c|c|c|c|c|c|c|c|c|}
\hline \multirow[b]{2}{*}{ Parameter $^{1}$} & \multirow[b]{2}{*}{$\begin{array}{l}\text { Ripening } \\
\text { time, d }\end{array}$} & \multicolumn{3}{|c|}{ Lamb rennet paste $^{2}$} & \multirow[b]{2}{*}{ SEM } & \multicolumn{3}{|c|}{ Effect, $P$-value } \\
\hline & & $\mathrm{RP}$ & RP-L & RP-B & & Rennet & Time & $\begin{array}{l}\text { Rennet } \\
\times \text { time }\end{array}$ \\
\hline \multirow[t]{3}{*}{ Moisture, \% } & 30 & $35.14^{\mathrm{a}}$ & $37.38^{\mathrm{b}}$ & $34.98^{\mathrm{a}}$ & & & & \\
\hline & 60 & $31.33^{\mathrm{a}}$ & $37.89^{c}$ & $34.13^{\mathrm{b}}$ & & & & \\
\hline & 120 & $29.68^{\mathrm{b}}$ & $29.90^{\mathrm{b}}$ & $26.46^{\mathrm{a}}$ & 0.2 & $* * *$ & $* * *$ & $* * *$ \\
\hline \multirow[t]{3}{*}{ Fat/DM, \% } & 30 & $37.27^{\mathrm{a}}$ & $42.45^{\mathrm{b}}$ & $41.76^{\mathrm{b}}$ & & & & \\
\hline & 60 & $42.42^{\mathrm{a}}$ & $43.55^{\mathrm{b}}$ & $44.20^{\mathrm{b}}$ & & & & \\
\hline & 120 & 42.42 & 42.43 & 41.74 & 0.3 & $* * *$ & $* * *$ & $* * *$ \\
\hline \multirow[t]{3}{*}{ Total FFA, \% } & 30 & $2.73^{\mathrm{a}}$ & $4.80^{\mathrm{c}}$ & $3.44^{\mathrm{b}}$ & & & & \\
\hline & 60 & $3.29^{\mathrm{a}}$ & $6.03^{c}$ & $5.93^{\mathrm{b}}$ & & & & \\
\hline & 120 & $5.20^{\mathrm{a}}$ & $6.61^{\mathrm{b}}$ & $6.25^{\mathrm{b}}$ & 0.31 & $* * *$ & $* * *$ & $* * *$ \\
\hline \multirow[t]{3}{*}{ Protein/DM, \% } & 30 & $30.01^{\mathrm{a}}$ & $35.15^{\mathrm{b}}$ & 33.36 & & & & \\
\hline & 60 & 26.71 & 27.74 & 26.99 & & & & \\
\hline & 120 & $68.16^{\mathrm{c}}$ & $44.42^{\mathrm{b}}$ & $35.46^{\mathrm{a}}$ & 1.47 & $* * *$ & $* * *$ & $* * *$ \\
\hline \multirow[t]{3}{*}{ Casein/DM, \% } & 30 & 24.80 & 28.94 & 26.60 & & & & \\
\hline & 60 & 21.65 & 22.15 & 20.02 & & & & \\
\hline & 120 & $61.48^{\mathrm{c}}$ & $37.95^{\mathrm{b}}$ & $30.19^{\mathrm{a}}$ & 1.54 & $* * *$ & $* * *$ & $* * *$ \\
\hline \multirow[t]{3}{*}{$\mathrm{NCN} / \mathrm{TN}$} & 30 & $15.55^{\mathrm{a}}$ & $20.95^{\mathrm{b}}$ & $23.12^{\mathrm{b}}$ & & & & \\
\hline & 60 & $18.92^{\mathrm{a}}$ & $20.01^{\mathrm{a}}$ & $25.86^{\mathrm{b}}$ & & & & \\
\hline & 120 & $9.79^{\mathrm{a}}$ & $14.54^{\mathrm{b}}$ & $14.93^{\mathrm{b}}$ & 0.76 & $* * *$ & $* * *$ & $*$ \\
\hline \multirow[t]{3}{*}{$\mathrm{NPN} / \mathrm{TN}$} & 30 & $10.08^{\mathrm{a}}$ & $13.74^{\mathrm{b}}$ & $17.55^{\mathrm{c}}$ & & & & \\
\hline & 60 & $12.62^{\mathrm{a}}$ & $14.07^{\mathrm{a}}$ & $19.36^{\mathrm{b}}$ & & & & \\
\hline & 120 & $8.52^{\mathrm{a}}$ & $12.94^{\mathrm{b}}$ & $12.74^{\mathrm{b}}$ & 0.7 & $* * *$ & $* * *$ & $*$ \\
\hline \multirow{3}{*}{$\mathrm{PASN} / \mathrm{TN}$} & 30 & $1.78^{\mathrm{a}}$ & $4.55^{\mathrm{b}}$ & $3.13^{\mathrm{b}}$ & & & & \\
\hline & 60 & $2.01^{\mathrm{a}}$ & $8.93^{\mathrm{b}}$ & $7.81^{\mathrm{b}}$ & & & & \\
\hline & 120 & $2.13^{\mathrm{a}}$ & $9.63^{\mathrm{b}}$ & $9.77^{\mathrm{b}}$ & 0.5 & $* * *$ & $* * *$ & $* * *$ \\
\hline \multirow[t]{3}{*}{$\mathrm{WSN} / \mathrm{TN}$} & 30 & $36.12^{\mathrm{a}}$ & $42.57^{\mathrm{b}}$ & $49.61^{\mathrm{c}}$ & & & & \\
\hline & 60 & $49.82^{\mathrm{a}}$ & $57.03^{\mathrm{b}}$ & $55.03^{\mathrm{b}}$ & & & & \\
\hline & 120 & $23.03^{\mathrm{a}}$ & $34.55^{\mathrm{b}}$ & $39.64^{\mathrm{c}}$ & 1.4 & $* * *$ & $* * *$ & $* *$ \\
\hline \multirow[t]{3}{*}{$\mathrm{PP} / \mathrm{TN}, \%$} & 30 & $26.04^{\mathrm{a}}$ & $28.83^{\mathrm{a}}$ & $32.06^{\mathrm{b}}$ & & & & \\
\hline & 60 & $32.67^{\mathrm{a}}$ & $37.21^{\mathrm{b}}$ & $42.96^{\mathrm{c}}$ & & & & \\
\hline & 120 & $14.51^{\mathrm{a}}$ & $21.61^{\mathrm{b}}$ & $26.91^{\mathrm{c}}$ & 1.1 & $* *$ & $* * *$ & $* * *$ \\
\hline
\end{tabular}

${ }^{\mathrm{a}-\mathrm{c}}$ Means within a row with different superscript letters differ $(P<0.05)$.

${ }^{1} \mathrm{NCN}=$ non-casein $\mathrm{N} ; \mathrm{TN}=$ total $\mathrm{N} ; \mathrm{NPN}=$ non-protein $\mathrm{N}$; PASN = phosphotungstic acid-soluble N; WSN $=$ water-soluble N; PP = proteosepeptone.

${ }^{2} \mathrm{RP}=$ rennet paste; RP-L = rennet paste containing encapsulated Lactobacillus acidophilus; RP-B = rennet paste containing encapsulated Bifidobacterium longum and Bifidobacterium lactis.

${ }^{*} P<0.05 ;{ }^{*} * P<0.01 ;{ }^{*} * * P<0.001$. 


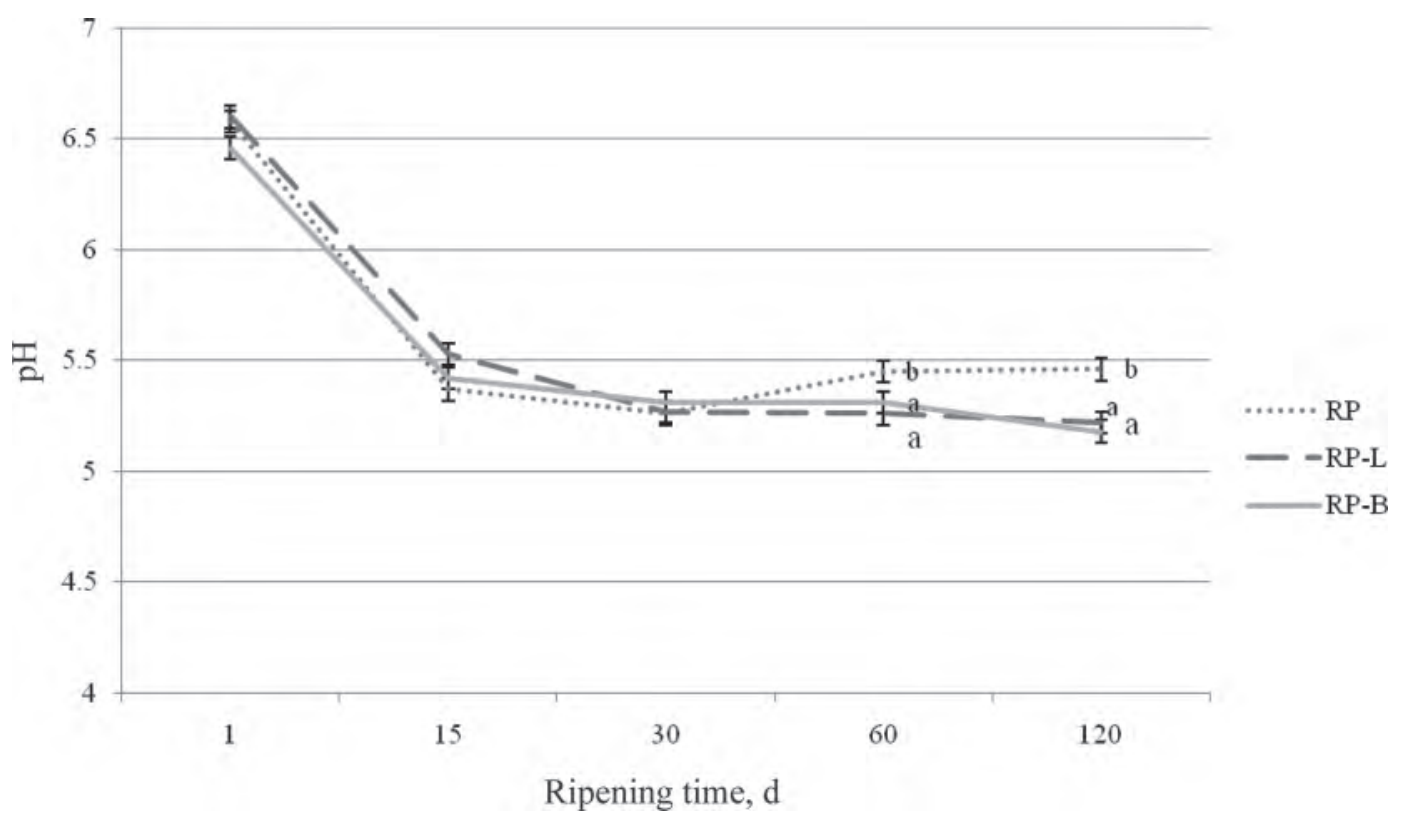

Figure 1. Evolution of $\mathrm{pH}$ in cheeses produced using different lamb rennet pastes. $\mathrm{RP}=$ rennet paste; RP-L $=$ rennet paste containing encapsulated Lactobacillus acidophilus; RP-B = rennet paste containing encapsulated Bifidobacterium longum and Bifidobacterium lactis. Means with different letters $(\mathrm{a}, \mathrm{b})$ differ at $P<0.05$ for each time of ripening. Color version available in the online PDF.

cheeses. No differences among cheeses were found for the other rheological parameters.

The evolution of $\mathrm{pH}$ in cheeses produced using different rennet pastes is reported in Figure 1; no differences were detected for this parameter among cheeses up to $30 \mathrm{~d}$ of ripening. With advancing ripening, an increase in the $\mathrm{pH}$ value is expected due to the catabolism of AA that leads to $\mathrm{NH}_{3}$ production and to metabolism of lactic acid. In this study, RP cheese underwent a slight increase in $\mathrm{pH}$ starting from $60 \mathrm{~d}$, whereas RP-L and $\mathrm{RP}-\mathrm{B}$ cheeses showed a stable $\mathrm{pH}$ value in the latest stages of ripening. Although RP-L and RP-B cheeses showed more intense proteolysis, the absence of a $\mathrm{pH}$ increase could be explained as an outcome of the metabolic activity of the probiotic liberated from alginate beads.

Linear correlations between enzymatic activities and $\alpha-$ and $\beta-\mathrm{CN}$ degradation products, WSN, and $\mathrm{PP}$ are shown in Table 6. No correlations were found in RP cheese between enzymatic activities and casein degradation products, whereas positive correlation was found between Ala-p-NA and WSN and PP. Negative correlation between Ala-p-NA, Pro-p-NA, and Argp-NA peptidases and $\beta-\mathrm{CN}$ degradation products in RP-B cheeses were found, whereas the same enzymatic activities were positively correlated with WSN and PP. Negative correlation between Leu-p-NA and Lys-p-NA peptidases and $\alpha-\mathrm{CN}$ degradation products and Arg-pNA, and Pro-p-NA peptidases and $\beta-\mathrm{CN}$ degradation products in RP-L were detected. The latter activities were also positively correlated with WSN and PP. The broad activity on different substrates, especially in RP-L cheese, may indicate the presence of different aminopeptidases, presumably types $\mathrm{N}$ and $\mathrm{A}$. The lack of correlations between enzymatic activities and ripening indexes and the lower values recorded for the same parameters in RP cheeses may indicate that enzymatic activity in cheese is mainly attributed to the presence of probiotic bacteria.

Principal component analysis of FFA in cheese produced using different rennet pastes during ripening are reported in Figure 2. The principal component analysis applied to FFA and CLA accounted for $80.38 \%$ of total variance; FFA content was the main factor explained by the first principal component, whereas the CLA content was the dominating factor along the second principal component. The RP cheeses were located in a well-defined zone of the plot, denoting a poorer FFA profile: total FFA at $60 \mathrm{~d}$ of ripening in RP cheese was half of the values reported in RP-L and RP-B, whereas at the end of the ripening time, the higher values were reported for RP-L, intermediate in RP-B, and lower in RP (Table 5). The RP-B cheeses moved along the first principal component as an outcome of an increase in FFA starting from $60 \mathrm{~d}$ of ripening. The score plot evidenced that RP-L cheese moved along the second principal component as a consequence of the enrichment in CLA in the cheese matrix, confirming the abil- 
Table 6. Correlation coefficients between casein degradation products, proteolysis indices, and enzymatic activities in cheeses produced using different lamb rennet pastes

\begin{tabular}{|c|c|c|c|c|c|}
\hline Item $^{1}$ & Leu- $p \mathrm{NA}^{2}$ & Lys- $p$ NA & Ala- $p \mathrm{NA}$ & Pro- $p$ NA & Arg- $p$ NA \\
\hline \multicolumn{6}{|l|}{$\mathrm{RP}$} \\
\hline$\beta-\mathrm{CN}$ degradation products & - & - & - & - & - \\
\hline$\alpha$-CN degradation products & - & - & - & - & - \\
\hline WSN & - & - & $0.79 * *$ & - & - \\
\hline $\mathrm{PP}$ & - & - & $0.78^{* *}$ & - & - \\
\hline RP-L & - & - & - & - & - \\
\hline$\beta-\mathrm{CN}$ degradation products & - & - & - & $-0.67^{* *}$ & $-0.51^{*}$ \\
\hline$\alpha-C N$ degradation products & $-0.53^{* * *}$ & $-0.67^{* *}$ & - & - & - \\
\hline WSN & - & - & - & $0.94^{* * *}$ & $0.56^{*}$ \\
\hline $\mathrm{PP}$ & - & - & - & $0.95^{* * *}$ & $0.56^{*}$ \\
\hline RP-B & - & - & - & - & - \\
\hline$\beta-\mathrm{CN}$ degradation products & - & - & $-0.60^{*}$ & $-0.71^{* *}$ & $-0.78^{* * *}$ \\
\hline$\alpha$-CN degradation products & - & - & - & - & - \\
\hline WSN & - & - & $0.60^{*}$ & $0.97^{* * *}$ & $0.85^{* * *}$ \\
\hline $\mathrm{PP}$ & - & - & - & $0.98^{* * *}$ & $0.86^{* * *}$ \\
\hline
\end{tabular}

${ }^{1} \mathrm{RP}=$ rennet paste; $\mathrm{WSN}=$ water-soluble nitrogen; $\mathrm{PP}=$ proteose-peptone; $\mathrm{RP}-\mathrm{L}=$ rennet paste containing encapsulated Lactobacillus acidophilus; RP-B = rennet paste containing encapsulated Bifidobacterium longum and Bifidobacterium lactis.

${ }^{2} p \mathrm{NA}=p$-nitroanilide.

${ }^{*} P<0.05 ;{ }^{* *} P<0.01 ;{ }^{* * *} P<0.001$.

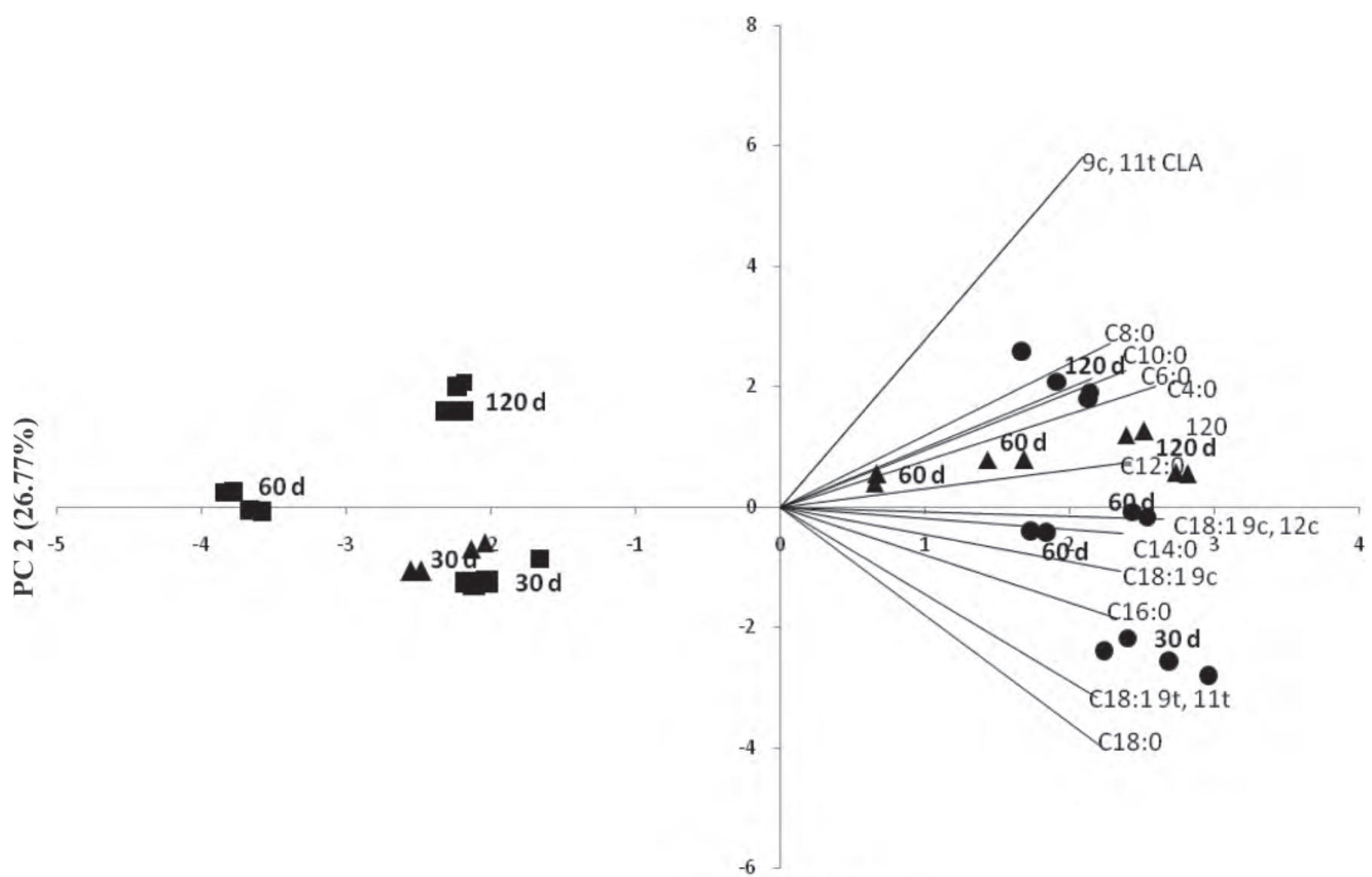

PC $1(53.66 \%)$

Figure 2. Principal component (PC) analysis of the FFA and conjugated linoleic acid (CLA) in cheese manufactured with different rennet pastes: - RP, lamb rennet paste; $-\mathrm{RP}-\mathrm{L}$, lamb rennet paste containing encapsulated Lactobacillus acidophilus; $\boldsymbol{\Delta}$ RP-B, lamb rennet paste containing encapsulated Bifidobacterium lactis and Bifidobacterium longum. 
ity of $L$. acidophilus to produce CLA from linoleic acid in the cheese matrix (Santillo et al., 2009).

\section{CONCLUSIONS}

Encapsulation of probiotic bacteria and their addition to rennet could be a successful way of protecting cells during cheese making. However, the effect of encapsulation and bead addition to rennet acted in a different way on the viability of probiotic. Lactobacillus acidophilus retained its viability for 4 to $5 \mathrm{~d}$ and then showed a fast reduction, whereas B. longum and $B$. lactis experienced kinetics characterized by an initial death slope, followed by a tail effect due to acquired resistance. After 1 mo of ripening, the massive bead disaggregation led to high cell counts of probiotics in cheeses; thus, the use of rennet containing encapsulated microorganisms sustained the production of functional Pecorino cheese from Gentile di Puglia ewe milk. Biochemical features in cheese ripened up to $120 \mathrm{~d}$ were influenced by the type of probiotic strain added to lamb rennet paste. Greater proteolysis was showed in cheese made with rennet paste containing a mix of $B$. longum and $B$. lactis due to the contribution of enzymes associated with these probiotic strains, whereas cheeses manufactured with lamb rennet paste containing $L$. acidophilus were characterized by a higher content of FFA and CLA.

\section{REFERENCES}

Albenzio, M., A. Santillo, M. Caroprese, R. Marino, A. Trani, and M. Faccia. 2010. Biochemical patterns in ovine cheese: Influence of probiotic strains. J. Dairy Sci. 93:3487-3496.

Albenzio, M., A. Santillo, M. Caroprese, L. Schena, D. E. Russo, and A. Sevi. 2011. Composition, indigenous proteolytic enzymes and coagulating behaviour of ewe milk as affected by somatic cell count. J. Dairy Res. 78:442-447.

Anal, A. K., W. F. Stevens, and C. Remuñán-López. 2006. Ionotropic cross-linked chitosan microspheres for controlled release of ampicillin. Int. J. Pharm. 312:166-173.

Andrews, A. T. 1983. Proteinases in normal bovine milk and their action on caseins. J. Dairy Res. 50:45-55.

Bergamini, C. V., E. R. Hynes, and C. A. Zalazar. 2006. Influence of probiotic bacteria on the proteolysis profile of a semi-hard cheese. Int. Dairy J. 16:856-866.

Bevilacqua, A., F. Cibelli, C. Cardillo, C. Altieri, and M. Sinigaglia. 2008. Metabiotic effects of Fusarium spp. on Escherichia coli O157:H7 and Listeria monocytogenes on raw portioned tomatoes. J. Food Prot. 71:1366-1371.

Blakesley, R. W., and J. A. Boezi. 1977. A new staining technique for proteins in polyacrylamide gels using Coomassie brilliant blue G250. Anal. Biochem. 82:580-582.

Bove, P., P. Russo, V. Capozzi, G. Spano, M. Albenzio, A. Gallone, and D. Fiocco. 2010. Stress tolerance of probiotic microorganisms in a simulated human gastro-intestinal system. Proceedings of the XII AIBG Congress.

Bustamante, M. A., M. Virto, I. Aramburu, L. J. R. Barron, F. J. Pérez-Elortondo, M. Albisu, and M. de Renobales. 2003. Lamb rennet paste in ovine cheese (Idiazabal) manufacture. Proteolysis and relationship between analytical and sensory parameters. Int. Dairy J. 13:547-557.

Champagne, C. P., N. Blahuta, F. Brion, and C. Gagnon. 2000. A vortex-bowl disk atomizer system for the production of alginate beads in a 1500-liter fermentor. Biotechnol. Bioeng. 68:681-688.

Corbo, M. R., M. Albenzio, M. De Angelis, A. Sevi, and M. Gobbetti. 2001. Microbiological and biochemical properties of Pecorino hard cheese supplemented with bifidobacteria. J. Dairy Sci. 84:551-561.

Corbo, M. R., A. Bevilacqua, and M. Sinigaglia. 2011. Shelf life of alginate beads containing lactobacilli and bifidobacteria: Characterisation of microspheres containing Lactobacillus delbrueckii ssp. bulgaricus. Int. J. Food Sci. Technol. 46:2212-2217. http:// dx.doi.org/10.1111/j.1365.2011.02739.x.

de Jong, C., and H. T. Badings. 1990. Determination of free fatty acids in milk and cheese. Procedures of extraction, clean up, and capillary gas chromatographic analysis. J. High Resol. Chromatogr. 13:94-98.

Di Cagno, R., I. De Pasquale, M. De Angelis, M. P. Calasso, S. Buchin, and M. Gobbetti. 2010. Contribution of selected adjunct or attenuated non-starter lactobacilli to ripening of Italian Caciotta cheese. Aust. J. Dairy Technol. 65:189-191.

El Soda, M., A. Macedo, and N. F. Olson. 1992. The peptide hydrolase system of Bifidobacterium species. Milchwissenschaft 47:87-90.

Geeraerd, A. H., C. H. Herremans, and J. F. Van Impe. 2000. Structural model requirements to describe microbial inactivation during mild heat treatment. Int. J. Food Microbiol. 56:185-209.

Gobbetti, M., A. Corsetti, E. Smacchi, M. De Angelis, and J. Rossi. 1997. Microbiology and biochemistry of Pecorino Umbro cheese during ripening. Italian J. Food Sci. 9:111-126.

Gripon, J.-C., M. J. Desmazeaud, D. Le Bars, and J. L. Bergere. 1975. Etude du rôle des micro-organismes et des enzymes au cours de la maturation des fromages. Lait 548:502-515.

IDF (International Dairy Federation). 1986. Cheese and processed cheese products. Determination of dry matter. FIL-IDF Standard No. 4. IDF, Brussels, Belgium.

IDF (International Dairy Federation). 1988. Determination of dry salt content. FIL-IDF Standard No. 12B. IDF, Brussels, Belgium.

IDF (International Dairy Federation). 1989. Determination of $\mathrm{pH}$. FIL-IDF Standard No. 115A. IDF, Brussels, Belgium.

Kailasapathy, K. 2002. Microencapsulation of probiotic bacteria: Technology and potential applications. Curr. Issues Intest. Microbiol. 3:39-48.

Khalid, N. M., and E. H. Marth. 1990. Lactobacilli-Their enzymes and role in ripening and spoilage of cheese: A review. J. Dairy Sci. $73: 2669-2684$.

Kuchroo, C. N., and P. F. Fox. 1982. Soluble nitrogen in Cheddar cheese: Comparison of extraction procedures. Milchwissenschaft $37: 331-335$.

Lawrence, R. C., L. K. Creamer, and J. Gilles. 1987. Texture development during cheese ripening. J. Dairy Sci. 70:1748-1760.

Mafart, P., O. Couvert, S. Gaillard, and I. Leguerinel. 2002. On calculating sterility in thermal preservation methods: Application of the Weibull frequency distribution model. Int. J. Food Microbiol. 72:107-113.

Morrison, W. R., and L. M. Smith. 1964. Preparation of fatty acids methyl esters and dimethylacetals from lipids with boron fluoridemethanol. J. Lipid Res. 5:600-608.

Prieto, B., I. Franco, J. G. Prieto, A. Bernardo, and J. Carballo. 2002. Proteolytic and lipolytic changes during the ripening of Leon raw cow's milk cheese, a Spanish traditional variety. Int. J. Food Sci. Technol. 37:661-671.

Remminghorst, U., and B. H. A. Rehm. 2006. Bacterial alginates: From biosynthesis to applications. Biotechnol. Lett. 28:17011712.

Rosburg, V., T. Boylston, and P. White. 2010. Viability of bifidobacteria strains in yogurt with added oat beta-glucan and corn starch during cold storage. J. Food Sci. 75:C439-C444.

Santillo, A., and M. Albenzio. 2008. Influence of lamb rennet paste containing probiotic on proteolysis and rheological properties of Pecorino cheese. J. Dairy Sci. 91:1733-1742. 
Santillo, A., and M. Albenzio. 2011. Focusing on lamb rennet paste: Combining tradition and innovation in cheese production. Chap. 17 in Food Engineering. B. C. Siegler, ed. Nova Science Publishers Inc., Hauppauge, NY.

Santillo, A., M. Albenzio, M. Quinto, M. Caroprese, R. Marino, and A. Sevi. 2009. Probiotic in lamb rennet paste enhances rennet lipolytic activity, and conjugated linoleic acid and linoleic acid content in Pecorino cheese. J. Dairy Sci. 92:1330-1337.

Santillo, A., M. Caroprese, R. Marino, A. Muscio, A. Sevi, and M. Albenzio. 2007. Influence of lamb rennet paste on composition and proteolysis during ripening of Pecorino foggiano cheese. Int. Dairy J. $17: 535-546$.

SAS Institute. 2011. SAS User's Guide: Statistics. Version 9.2 ed. SAS Inst. Inc., Cary, NC.

Shapiro, S. S., and M. Wilk. 1965. An analysis of variance test for normality. Biometrika 52:591-611.

Shihata, A., and N. P. Shah. 2000. Proteolytic profiles of yogurt and probiotic bacteria. Int. Dairy J. 10:401-408.
Stadhouders, J. 1960. The hydrolysis of protein during ripening of Dutch cheese. The enzymes of the bacteria involved. Neth. Milk Dairy J. 14:106-110.

Sultana, K., G. Godward, N. Reynolds, R. Arumugaswamy, P. Peiris, and K. Kailasapathy. 2000. Encapsulation of probiotic bacteria with alginate-starch and evaluation of survival in simulated gastrointestinal conditions and in yogurt. Int. J. Food Microbiol. 62:47-55.

Trujillo, A. J., B. Guamis, J. Laencina, and M. B. López. 2000. Proteolytic activities of some milk clotting enzymes on ovine casein. Food Chem. 71:449-457.

Vinderola, C. G., and J. A. Reinheimer. 1999. Culture media for the enumeration of Bifidobacterium bifidum and Lactobacillus acidophilus in the presence of yoghurt bacteria. Int. Dairy J. 8:497-505.

Wallace, J. M., and P. F. Fox. 1997. Effect of adding free amino acids to Cheddar cheese curd on proteolysis, flavor and texture development. Int. Dairy J. 7:157-167. 